UDC 616.2-022.6-053.37-058.86

DOI: $10.21668 /$ health.risk/2020.1.08.eng

\title{
DYNAMICS OF ACUTE MORBIDITY AND RISK FACTORS THAT CAUSE FREQUENT ACUTE RESPIRATORY TRACT INFECTIONS IN INFANT CHILDREN DURING THEIR FIRST YEAR IN A FOSTER FAMILY
}

\author{
O.Yu. Kocherova ${ }^{1}$, E.N. Antysheva ${ }^{1}$, V.V. Chubarovsky ${ }^{2}$, O.M. Filkina ${ }^{1}$, E.A. Vorobeva ${ }^{1}$ \\ ${ }^{1}$ V.N. Gorodkov's Ivanovo Scientific Research Institute for motherhood and childhood, 20 Pobedy Str., Ivanovo, \\ 153045, Russian Federation \\ ${ }^{2}$ National Medical Research Center for Children's Health, Bld. 1, 2 Lomonosovskiy Ave., Moscow, 119991, \\ Russian Federation
}

Our research goal was to study dynamics of acute morbidity and reveal risk factors that caused frequent acute respiratory tract infections (acute RTIs) in infant children during their first year in a foster family (FF).

We examined health of 100 infant children at the moment they were adopted and after a year spent in a foster family; we also examined psychological peculiarities their foster mothers had. Our control group included 90 infant children of the same age who lived with their blood parents and their mothers. We studied social and biological case histories and performed clinical examinations of children. Psychological examinations of foster mothers and parent-child relations in families were performed with mini MMPI tests, procedures developed by Yu.A. Alyoshina, L.Ya. Gozman and E.M. Dubovskaya; A.Ya. Varg; V.V. Stolin; E.G. Eidemiller and V.V. Yustitskis. We applied Wald's sequential analysis to draw up an expectancy table.

Our research allowed us to reveal that infant children who had spent a year in a foster family were more frequently assigned into "often ill" category than children who lived with their blood parents. Adopted children tended to suffer from complicated acute RTIs more frequently. We detected several risk factors that could cause frequent acute respiratory infections; they were a child being born in the second or more delivery; reduced or drastically reduced resistance at the moment a child was adopted; a foster family being a one-parent one; insufficient amount of time spent by a foster mother with a child; such personality traits in a foster mother as impulsivity, masculinity, eccentricity, emotional immaturity; parents being primarily oriented at autonomous activities; a significant psychological distance between foster parents and a child; parents not treating a baby as an infant and ignoring its needs. We developed a forecast for acute respiratory tract infections in children during their adaptation in a new family taking into account not only biological factors, but also social and psychological ones.

Key words: risk factors, acute respiratory tract infections, children, infancy, foster families, social and biological case history, a psychological profile of a mother, parent-child relations.

Abandoned children who are deprived of parent care need help; it is a key priority of any state to provide it. Activities performed in the sphere and aimed at supporting such children are vital components in social policies [1].
A number of children who are left without parent care in their infancy is growing. $75 \%$ of all children who are annually placed in orphanages are infants younger than 12 months; such children are abandoned by their mothers

(C) Kocherova O.Yu., Antysheva E.N., Chubarovsky V.V., Filkina O.M., Vorobeva E.A., 2020

Olga Yu. Kocherova - Doctor of Medical Sciences, Leading Researcher at the Children's Health Protection Department (e-mail: ivniideti@mail.ru; tel.: +7 (961) 246-24-41; ORCID: https://orcid.org/0000-0002-2473-8339).

Elena N. Antysheva - post-graduate student (e-mail: Ant_elena@list.ru; tel.: +7 (920) 345-45-00; ORCID: https://orcid.org/0000-0003-0359-0846).

Vladimir V. Chubarovsky - Doctor of Medical Sciences, Leading Researcher (e-mail: chubarovskiy@gmail.com; tel.: +7 (926) 219-97-00; ORCID: https://orcid.org/0000-0002-4108-6969).

Olga M. Filkina - Doctor of Medical Sciences, Professor, Honored Physician of the Russian Federation, Head of the Children's Health Protection Department (e-mail: omfilkina@mail.ru; tel.: +7 (903) 888-91-94; ORCID: https:// orcid.org/0000-0003-2228-748X).

Elena A.Vorobeva - Doctor of Medical Sciences, Leading Researcher at the Children's Health Protection Department (e-mail: ivniideti@mail.ru; tel.: +7(909)249-88-44; ORCID: https://orcid.org/0000-0003-2820-9714). 
in maternity hospitals in $96.4 \%$ cases $[2,3]$. Practically all such children initially have unfavorable conditions for formation of their health. Many authors stress that such children, as a rule, are unwanted and have burdened social and biological case history; they are often born by mothers who are too young; smoking mothers; mothers who drink alcohol and take drugs during pregnancy; mothers who pursue asocial lifestyle; there are also impacts exerted by disorders in their intrauterine development and diseases in the neonatal period [4-6].

Early and long-term separation from a mother produces grave negative effects on a child's health and development, causes neurotic and affective disorders; a child experiences fear and aggression and doesn't trust anyone [7-9]. Infant children tend to react on the somato-vegetative level and children who are left without parent care obligatorily have various signs of neuropathic syndrome (increased overall and vegetative excitability, proneness to digestive and sleep disorders, absence of any skills to keep oneself tidy, and lower resistance) $[7,10,11]$.

Issues related to health of orphans who were raised in state orphanages have been given considerable attention in scientific literature. As per data provided by many authors, from $25 \%$ to $47 \%$ orphans raised in state orphanages belong to "often sick" category $[4,5,12,13]$.

It was proven that orphans and children left without parent care who were adopted by foster families (FF) had better health than children who were left in orphanages; however, even after being adopted, such children were still behind their counterparts who lived with their blood parents as per many parameters $[3,9,14,15]$.

Adaptation to a new family to a great extent depends on a child's age; parents' personal traits; relations existing in a foster family; somatic and mental health of a child and foster parents; parents' psychological competence $[16,17]$.

According to available data, children who had been adopted by a foster family developed rapidly during the first year after adoption; it was especially true for physical and neuropsychic development. However, there were great difficulties related to children adapting to foster families in $17.5 \%$ cases $[16,18,19]$.

Children still are not fully adapted to a foster family after the first year spent in it despite more favorable micro-social conditions there than in an orphanage. Adopted children tend to have lower resistance that results from negative impacts exerted by biological and social factors on infants (burdened heredity; unfavorable clinic course of pregnancy and birth; irrational nutrition and improper care; asocial parents being cruel or careless; a child being raised in an orphanage and it leading to social deprivation). An adopted child is placed in a new micro-social environment and it makes him or her feel afraid and diffident, dependent on external circumstances and unknown people; any affection to foster parents is to occur under such unfavorable conditions [18-20]. We revealed that infant children still had lower resistance during their first year spent in a foster family [21].

There are no sufficient data on health of infant children adopted by foster families in scientific literature; besides, available data are rather contradictory. It calls for a longitudinal study and search for new biological, social, and psychological markers that can be used as predictive criteria. Implementation of prediction technologies will allow performing prevention activities in due time.

Our research goal was to examine dynamics of acute morbidity and determine risk factors that cause frequency acute respiratory tract infections (RTIs) in small children during their first year in a foster family.

Research techniques. We examined health of 100 children aged 1-3 at the moment they were adopted by a foster family and after they spent 1 year in that family; we also examined psychological peculiarities of their foster mothers. Our reference group was made up of 90 children of the same age who lived with their blood parents and their mothers. To draw up our prediction, we divided children who 
lived in foster families into two groups; the $1^{\text {st }}$ one included children who suffered from acute RTIs 6 times per year or even more often, and the $2^{\text {nd }}$ one was made up of children who didn't have RTIs or had them so often (less than 6 times per year).

We examined social and biological case histories via taking data from medical documents, questioning and interviewing parents. All the children had clinical check-ups and their medical documents were examined; we questioned foster parents using our own structured clinical-statistic chart.

All the examinations were performed with obligatory adherence to ethical standards fixed in Helsinki Declaration (1975, supplemented in 1983 and 1989). Parents (legal representatives) of all children gave their informed voluntary consent to medical intervention and personal data processing.

We accomplished psychological examination on foster mothers in order to reveal their personal traits and it was done with mini MMPI test; attitudes accepted by a married couple were revealed with a procedure developed by Yu.A. Alyoshina, L.Ya. Gozman and E.M. Dubovskaya; parent - child relations were studied with procedures developed by A.Ya. Varg and V.V. Stolin; family relations were examined with procedures developed by E.G. Eidemiller and V.V. Yustitskis.

All the data were statistically processed with MS Excel XP and Statistica 6.0.

We applied Wald's sequential analysis to draw up our expectancy table. First, we proved that there were authentic discrepancies in frequency of an examined factor among children who were often sick with acute RTIs, who were sick on rare occasions, and who didn't fall sick; having done that, we calculated predictive quotients (PQ) for each factor gradation. Predictive quotient was calculated as per the following formula: $\mathrm{PQ}=10 \lg (\mathrm{P} 1 / \mathrm{P} 2)$ provided a factor was present; $\mathrm{PQ}=10 \mathrm{lg}(1-\mathrm{P} 1 / 1-\mathrm{P} 2)$ provided that a factor was absent, where $\mathrm{P} 1$ and $\mathrm{P} 2$ were frequencies of an examined factor in groups that were being compared. A positive value meant a forecast was unfavorable.
Results. Most small children (71\%) were ranked as "sick on rare occasions" at the moment they were adopted by a foster family; a number of "often sick" children was 6.3 times higher than a number of children who didn't fall sick ( $25 \%$ against $4 \%)$. There were almost no changes in a number of children in all three groups after they had spent a year in a foster family ( $71 \%$ against $70 \% ; 25 \%$ against $24 \% ; 4 \%$ against $6 \%$ ). However, a number of children who were ranked as "often sick" was 2.7 times higher among children from foster families than among children who lived with their blood parents $(8.8 \%$ against $24 \%, p=0,007)$; a number of children who didn't fall sick was 2.8 times lower among children from foster families than among those who lived with their blood parents $(16.6 \%$ against $6 \%, \mathrm{p}=0,033)$.

We analyzed peculiarities related to clinical course of acute RTIs among children from different groups and revealed that $87 \%$ small children suffered from acute RTIs with complications at the moment they were adopted by a foster family. Complications were predominantly diseases in the lower respiratory tracts, such as acute bronchitis, acute obstructive bronchitis, tracheobronchitis $(80 \%)$, and pneumonia $(19 \%)$. Besides, there were such complications as acute conjunctivitis $(37 \%)$, acute otitis $(33 \%)$, obstructing laryngotracheitis (12\%), and pharyngitis $(5 \%)$.

After adopted children spent their first year in a foster family, there was a descending trend in a number of acute RTIs with complications ( $87 \%$ against $77 \%$ ), and an ascending one for acute RTIs without any complications (13\% against $23 \%$ ). As for structure of occurring complications, there was an authentic decrease in frequency of acute bronchitis, acute obstructive bronchitis, tracheobronchitis $(80 \%$ against $58 \%, \mathrm{p}=0.007)$, and pneumonia (19\% against $7 \%, p=0.035)$, whereas a share of pharyngitis increased by 4 times $(5 \%$ against $20 \%, p=0.007$ ), and there was an ascending trend in frequency of acute otitis (33\% against $47 \%$ ). 
Children who were adopted by foster families had acute RTIs without complications two times less frequently than children who lived with their blood parents (46\% against $23 \%, p=0.001)$; they suffered from acute RTIs with complications authentically more frequently $(54 \%$ and $77 \%, p=0.001)$. Children from foster families more frequently had such complications as acute bronchitis, acute obstructive bronchitis, tracheobronchitis (58\% against $39 \%, \mathrm{p}=0.034$ ), acute conjunctivitis (33\% against $24 \%$ ), and acute otitis (47\% against $34 \%$ ).

Therefore, after their first year in a foster family, children were more frequently ranked as "often sick" than children who lived with their blood parents; children from foster families more frequently suffered from acute RTIs with complications which were predominantly diseases in the lower respiratory tracts. So, it is important to predict frequent acute RTIs for children who are adopted by foster families.

Basing on analysis of social, psychological, and biological factors, we revealed the most significant risk factors; they were a child being born in the $2^{\text {nd }}$ and the subsequent births; reduced and extremely reduced resistance at the moment a child is adopted; a foster family being one-parent; a foster mother not spending enough time with a child; a foster mother being emotionally unstable (she had such personality traits as impulsivity, masculinity, eccentricity, and emotional immaturity); parents being predominantly oriented at autonomous activities; a significant psychological distance between parents and a child; parents not treating a baby as an infant and ignoring its needs.

We created an expectancy table to predict frequent acute RTIs (Table).

An expectancy table to predict frequent acute RTIs in small children during their first year in a foster family

\begin{tabular}{|l|c|}
\hline \multicolumn{1}{|c|}{ Risk factors } & PQ \\
\hline Biological factors & \\
\hline A child being born in the $2^{\text {nd }}$ or subsequent births & +2.30 \\
\hline - yes & -3.49 \\
\hline - no & \\
\hline Reduced and extremely reduced resistance at the moment a child is adopted & +3.65 \\
\hline - yes & -3.17 \\
\hline - no & \\
\hline Social factors & \\
\hline One-parent foster family & +3.36 \\
\hline - yes & -1.87 \\
\hline - no & \\
\hline A foster mother spending with a child not more than 6 hours a day & +1.58 \\
\hline - yes & -6.69 \\
\hline - no & \\
\hline Psychological factors & \\
\hline Personality traits of a foster mother (mini MMPI test): & +6.88 \\
\hline Self-conceit, impulsiveness & -2.54 \\
\hline - yes & \\
\hline - no & +4.49 \\
\hline $\begin{array}{l}\text { A desire to stress decisiveness and masculinity; difficulties in interpersonal communi- } \\
\text { cation }\end{array}$ & -2.74 \\
\hline - yes & +10.80 \\
\hline - no & -1.48 \\
\hline Eccentricity & \\
\hline - yes & \\
\hline - no & \\
\hline
\end{tabular}




\begin{tabular}{|l|c|}
\hline Emotional immaturity, hypomania & \\
\hline - yes & +4.45 \\
\hline - no & -2.15 \\
\hline Parents - child relations (procedure by A.Ya. Varg and V.V. Stolin): & \\
\hline A significant psychological distance between parents and a child & +8.75 \\
\hline - yes & -3.39 \\
\hline - no & \\
\hline Treating baby as an infant & +1.10 \\
\hline - yes & -13.63 \\
\hline - no & +7.20 \\
\hline Ignoring baby's needs (U scale in family relations analysis) & -1.13 \\
\hline - yes & \\
\hline - no & +2.20 \\
\hline $\begin{array}{l}\text { Parents being predominantly oriented at autonomous activities (test developed by } \\
\text { Yu.A. Alyoshina, L.Ya. Gozman and E.M. Dubovskaya) }\end{array}$ \\
\hline - yes & -4.26 \\
\hline - no & \\
\hline
\end{tabular}

Note: PQ means predictive quotient.

To predict acute RTIs, a pediatrician from an orphanage takes data from a child's case history and applies an expectancy table to determine whether risk factors are present or absent. A psychologist at a support center for foster families should accomplish a psychological examination of a foster mother with specific test and reveal probable psychological risk factors.

Should a sum of all PQs be equal to +13 scores or higher, it means a child is going to be often sick with acute RTIs. Should this sum be equal to -13 scores or lower, it means absence of acute RTIs. Should the PQs sun be between -13 and +13 scores, it means there are not enough data in this case to make any prediction.

When a forecast for a child from a risk group is unfavorable, a pediatrician prescribes differentiated preventive activities; in case of necessity a consultation and examination by an immunologist is required; a pediatrician also develops and implements an individual program aimed at supporting a foster family as it will allow reducing risks of frequent acute RTIs; such programs require psychologists' participation.

\section{Conclusions.}

1. Small children, even after a year spent in a foster family, more frequently fall sick with acute RTIs than children who live with their blood parents. They also more frequently suffer from RTIs with complications which are predominantly diseases in the lower respiratory tracts. Therefore, when children are adopted by foster families, it is important to predict frequent acute RTIs.

2. Significant risk factors that cause frequent acute RTIs among children adopted by foster families are as follows: a child being born in the 2nd and the subsequent births; reduced and extremely reduced resistance at the moment a child is adopted; a foster family being one-parent; a foster mother not spending enough time with a child. Psychological risk factors are such personality traits of a foster mother as impulsivity, masculinity, eccentricity, and emotional immaturity; parents being predominantly oriented at autonomous activities; a significant psychological distance between parents and a child; parents not treating a baby as an infant and ignoring its needs.

3. We developed a procedure for predicting acute RTIs in small children during their first year in a foster family. Implementation of prediction technologies will allow accomplishing preventive activities in due time.

Funding. The research was not granted any sponsor support.

Conflict of interests. The authors declare there is no any conflict of interest. 


\section{References}

1. Al'bitskii V.Yu., Pozdnyakova M.A., Ibragimov A.I., Gasilovskaya T.A. Mediko-sotsial'nye problem sirotstva v sovremennoi Rossii [Medico-social problems of orphans in modern Russia]. Aktual'nye problem sotsial'noi pediatrii: izbrannye ocherki. Sotsial'naya pediatriya, 2012, pp. 160-168 (in Russian).

2. Manerova O.A., Markina A.Yu. The features of reproductive anamnesis and mother's medical activity who abandoned their children in maternity facilities. Ural'skii meditsinskii zhurnal, 2019, no. 2, pp. 133-137 (in Russian).

3. Zakirov F.I. Comparative analysis of psychological development of children brought up in infant orphanages and in foster families. Aspirantskii vestnik Povolzh'ya, 2014, no. 5-6, pp. 39-42 (in Russian).

4. Akcinar B., Baydar N. Development of externalizing behaviors in the context of family and non-family relationships. Journal of Child and Family Studies, 2016, vol. 25, no. 6, pp. 1848-1859. DOI: $10.1007 / \mathrm{s} 10826-016-0375-\mathrm{Z}$

5. Allamyarova N.V., Alekseeva V.M. Forecasting individual morbidity among children living in specialized orphanages (exemplified by Moscow region). Sotsial'nye aspekty zdorov'ya naseleniya, 2014, vol. 40, no. 6, pp. 13-14 (in Russian).

6. Bell T., Romano E., Flynn R.J. Profiles and predictors of behavioral resilience among children in child welfare. Child Abuse and Neglect, 2015, vol. 48, pp. 92-103. DOI: 10.1016/j.chiabu.2015.04.018

7. Portnova A.A., Serebrovskaya O.V. Ostrye stressovye narusheniya u detei rannego vozrasta [Acute stress disorders in infant children]. Psikhiatriya, 2013, vol. 60, no. 4, pp. 37-40 (in Russian).

8. Bowlby J. Sozdanie i razrushenie emotsional'nykh svyazei [Emotional bonds created and destructed]. In: V.V. Starovoitova ed. Moscow, Akademicheskii Proekt Publ., 2004, 232 p. (in Russian).

9. Nikolaeva E.I. The relationship of the child's intellect with the duration of staying at an orphanage (on the example of foster families of the republic of Khakassia). Psikhologiya obrazovaniya $v$ polikul'turnom prostranstve, 2016, vol. 35, no. 3, pp. 25-33 (in Russian).

10. Aslamazova L.A., Mukhamedrakhimov R.Zh., Vershinina E.A. Institutional experience and level of health as factors of behavior specificity of children in substitute families. Psikhologicheskii zhurnal, 2019, vol. 40, no. 1, pp. 47-58 (in Russian).

11. Mashina N.S., Galaktionova M.Yu. Health status of infants and its determining factors. Sibirskoe meditsinskoe obozrenie, 2015, vol. 92, no. 2, pp. 26-31 (in Russian).

12. Lezhnina I.V., Lyapunova E.V., Ponomareva O.V. Sostoyanie zdorov'ya detei, vospityvayushchikhsya $\mathrm{v}$ domakh rebenka [Health of children raised in orphanages]. Rossiiskii vestnik perinatologii i pediatrii, 2019, vol. 64, no. 4, pp. 321-322 (in Russian).

13. Gabrielli J., Jackson Y., Brown S. Associations between maltreatment history and severity of substance use behavior in youth in foster care. Child Maltreatment, 2016, vol. 21,no. 4, pp. 298-307. DOI: $10.1177 / 1077559516669443$

14. Goemans A., Van Geel M., Vedder P. Over three decades of longitudinal research on the development of foster children: A meta-analysis. Child Abuse and Neglect, 2015, vol. 42, pp. 121-134. DOI: $10.1016 /$ j.chiabu.2015.02.003

15. Hayes M.J., Geiger J.M., Lietz C.A. Navigating a complicated system of care: foster parent satisfaction with behavioral and medical health services. Child and Adolescent Social Work Journal, 2015, vol. 32, no. 6, pp. 493-505. DOI: 10.1007/s10560-015-0388-2

16. Grebennikova E.V., Firsova O.V. Social-psychological adoptation of organ children in adopted families. Vestnik TGPU, 2009, vol. 82, no. 4, pp. 51-55 (in Russian).

17. Chasovskikh A.V., Solodunova M.Yu. Osobennosti vyrazheniya emotsii det'mi v zameshchayushchikh sem'yakh [Peculiarities related to expressing emotions by children raised in foster families]. Psikhologiya XXI veka: Psikhologiya kak nauka, iskusstvo i prizvanie: Sbornik nauchnykh trudov uchastnikov nauchnoi konferentsii molodykh uchenykh. In: A.V. Shaboltas, S.D. Guriev eds. SanktPeterburg, 2018, pp. 389-395 (in Russian).

18. Morozova I.S., Belogai K.N., Ott T.O. Special features of children-parents relations in foster families. Vestnik Kemerovskogo gosudarstvennogo universiteta, 2014, vol. 3, no. 3-3 (59), pp. 146-151 (in Russian). 
19. Dekina E.V., Egorov V.S. Study of child and parental relations in the deputy family. Gumanitarno-pedagogicheskie issledovaniya, 2019, vol. 3, no. 3, pp. 18-25 (in Russian).

20. Johnson E. Help seeking among adolescents in foster care: A qualitative study. University of Windsor. Electronic Theses and Dissertations, 2014, 115 p. Available at: https://scholar.uwindsor.ca/ cgi/viewcontent.cgi?article $=6231 \&$ context $=$ etd (12.01.2019).

21. Kocherova O.Yu., Fil'kina O.M., Vorob'eva E.A., Dolotova N.V., Pykhtina L.A., Shanina T.G., Antysheva E.N., Nazarov S.B. Features of physical illness, physical and neuropsychological development and their dynamics in infants in fosterage to fostering families. Verkhnevolzhskii meditsinskii zhurnal, 2013, vol. 11, no. 4, pp. 15-18 (in Russian).

Kocherova O.Yu., Antysheva E.N., Chubarovsky V.V., Filkina O.M., Vorobeva E.A. Dynamics of acute morbidity and risk factors that cause frequent acute respiratory tract infections in infant children during their first year in a foster family. Health Risk Analysis, 2020, no. 1, pp. 76-82. DOI: 10.21668/health.risk/2020.1.08.eng

Received: 09.12.2019

Accepted: 09.02.2020

Published: 30.03.2020 